SHORT COMMENTARY

\title{
Seniors and Diabetes Education on Social Media
}

\section{Edson da Silva ${ }^{1 *}$, Marileila Marques Toledo ${ }^{1,2}$ and Luciana de Freitas Campos ${ }^{1,3}$}

${ }^{1}$ Group of Studies and Research on Diabetes, Department of Basic Sciences, Federal University of Jequitinhonha and Mucuri Valleys (UFVJM), Diamantina, Brazil

${ }^{2}$ Master Degree Student in Health, Society and Environment, Federal University of Jequitinhonha and Mucuri Valleys (UFVJM), Diamantina, Brazil

${ }^{3}$ Department of Nursing, Federal University of Jequitinhonha and Mucuri Valleys (UFVJM), Diamantina, Brazil

*Corresponding author: Edson da Silva, Group of Studies and Research on Diabetes, Department of Basic Sciences, Federal University of Jequitinhonha and Mucuri Valleys (UFVJM), Campus JK, Edifíicio DCB-DCBio, SI 129, CEP: 39100-000, Diamantina, Minas Gerais, MG, Brazil, Tel/Fax: +55-38-3532-1200, E-mail: edsondasilvaatm@hotmail.com

The growing life expectancy of the population has shown significant increase in the number of elderly $[1,2]$ and seniors have more diabetes than any other age-group $[3,4]$. Worldwide, the number of people aged 60 or older is growing faster than all younger age groups, with most of the increase in developing countries. In 2017, there are an estimated 962 million people aged 60 or over in the world, comprising 13 per cent of the global population. The number of older persons in the world is projected to be 1.4 billion in 2030 and 2.1 billion in 2050, and could rise to 3.1 billion in 2100 [2]. Currently, almost one-third of United States adults over the age of 65 years have diabetes [5]. Globally, it is estimated that about $30 \%$ of older adults meet the criteria for diabetes diagnosis and a 4.5 -fold increase in those aged 65 years and older with diabetes has been projected from 2005 to 2050 [6].

The use of new technologies and social networks on the Internet offers opportunities for easy access to self-care and diabetes education [7-9]. Additionally, technology becomes increasingly important in the daily lives of patients and health professionals. Different materials and virtual tools are available to users, including forums, e-books, videos, texts, images, courses, podcasts, scientific papers, summaries of innovative research about the management and treatment of chronic diseases like diabetes and other interesting kinds of common and scientific information [7]. In this context, currently seniors use the Internet, especially Facebook as a communication tool, interaction, social inclusion, combating loneliness and as a way of learning throughout the aging process $[10,11]$. Therefore, it becomes important to understand the general characteristics of seniors followers of social networks such as Facebook. Thus, health communication strategies can be improved to achieve this elderly population.

However, the senior population is one of the groups where strong incidences of digital exclusion can be found [10]. Moreover, the use of Information and Communication Technologies can facilitate the access of seniors to the knowledge society, especially in family and social relations can be a motivation for greater coexistence and consequently improvement in their welfare [12]. Digital media have become present everywhere at the same time and easier to use, via the internet, tablets, and smartphones. Being online has become compelling, as much information, goods, services, and people are most available online. Although older people may lose some ties with workmates as they retire, they gain more leisure time to connect with friends and relatives [13].

Although seniors have lower rates of technology adoption than the general public, this group is more digitally connected nowadays $[10,11]$. Considering the high and increasing number of seniors with diabetes in the world [3], strategies need to be developed to raise awareness among young persons about the importance of seeking and sharing reliable information about the disease, as a tool for the care of elderly people in their surroundings. 
The access to technology and the Internet may provide opportunities to reduce risks of social exclusion among seniors with diabetes. However, the technology can't replace human contact, but should to offer additional opportunities to seniors remain connected. Furthermore, special attention should be directed to young persons, because they are directly involved with diabetes management of older persons. So, in future, it would be important to explore the use of technologies and social networks on the Internet by seniors in order to evaluate the impact of this learning kind on the promotion of active aging and also propose diabetes education programs for make it more attractive to this community.

\section{References}

1. Silva APD, Pureza DYD, Landre CB (2015) Frailty syndrome in elderly patients with type 2 diabetes mellitus. Acta Paul Enferm 28: 503-509.

2. United Nations Department of Economic and Social Affairs/ Population Division (2017) World Population Prospects: The 2017 Revision. Key Findings and Advance Tables. Working Paper No. ESA/P/WP/248.

3. IDF (2016) International Diabetes Federation.

4. Briscoe VJ (2014) Older Adults and Diabetes. Diabetes Spectr 27: 6-7.

5. Kalyani RR, Golden SH, Cefalu WT (2017) Diabetes and aging: Unique considerations and goals of care. Diabetes Care 40: 440-443.
6. Strotmeyer ES, Zgibor JC (2015) Diabetes and aging. Clin Geriatr Med 31: xiii-xvi.

7. da Silva E, Campos LF (2016) The potential role of social media and interactive technologies in diabetes education. $J$ Dia Res Ther 2: e103.

8. da Silva E, Costa JSR, Figueiredo EAB, Cunha MD, de Castro DP, et al. (2015) Diabetes diamantina community: a tool to promote communication and education in diabetes. Diabetol Metab Syndr 7: 175.

9. Van der Molen P, Maas AH, Chen W, van Pul C, Cottaar EJE, et al. (2017) Identifying user preferences for a digital educational solution for young seniors with diabetes. Diabetes Spectr 30: 182-187.

10. Páscoa GMG, Gil HMPT (2015) Uma nova forma de comunicação para o cidadão Sénior: Facebook. Revista Kairós Gerontologia 18: 09-29.

11. Jung EH, Sundar SS (2016) Senior citizens on Facebook: How do they interact and why? Computers in Human Behavior 61: 27-35.

12. Mincache GB, Lodovici FMM, Côrte B, de Toledo Nóbrega O, Santana MA (2011) Aliando Tecnologia da Aprendizagem à Qualidade da Vida Idosos. Redes. Com: Revista de Estudios Para el Desarrollo Social de la Comunicación 6: 291-299.

13. Quan-Haase A, Mo GY, Wellman B (2017) Connected seniors: how older adults in east york exchange social support online and offline. Information, Communication \& Society 20 : 967-983. 